\title{
Análise da percepção ambiental sobre os parques urbanos da cidade de Manaus, Amazonas.
}

\author{
Álefe Lopes Viana', Marcileia Couteiro Lopes², Nelson Felipe de Albuquerque Lins Neto³, \\ Stephany Anry Kudo, David Franklin da Silva Guimarães ${ }^{5}$, Maikel Lamego Guimarães Mari ${ }^{6}$ \\ 1,3Universidade Federal do Amazonas - UFAM. \\ 'Universidade Federal do Amazonas - UFAM', Faculdade de Ciências Agrárias, Dpto. de Ciências Florestais \\ ${ }^{4}$ mestranda em Ciências do Ambiente e Sustentabilidade na Amazônia (UFAM) \\ ${ }^{5}$ Universidade Federal do Amazonas - Acadêmico de Engenharia Florestal (UFAM). \\ ${ }^{6}$ Instituto Nacional de Pesquisas da Amazônia (INPA).
}

\section{Resumo}

A temática "meio ambiente", hoje em dia, está cada vez mais sendo inserida na sociedade. O meio ambiente natural foi substituído por espaços urbanos, sendo estes palcos de relações entre a comunidade humana e seu meio físico. O espaço urbano é composto por uma gama de variações de usos, entre eles habitacionais, comerciais, industriais, recreativos, parques urbanos, dentre outros. Mesmo diante de tantos benefícios ambientais e sociais, os espaços verdes não têm sido um uso prioritário no espaço urbano. A sociedade admite que condições ambientais adequadas é determinante na utilização destas áreas, contribuindo para a promoção da saúde e bem estar. Neste sentido, o presente estudo teve o objetivo de analisar a percepção ambiental dos estudantes sobre os parques urbanos de Manaus, com intuito de melhor compreender suas necessidades direcionadas para o bem-estar, recreação, lazer, etc. Para tanto foi aplicado um questionário com 18 perguntas para 110 entrevistados. Ao fim da análise pode-se constatar que alguns termos e situações ambientais ainda não são claros para os entrevistados; nem todos os entrevistados possuem interesse em atividades e em práticas ambientais, demonstrando baixo nível de importância; há uma pequena parte de pessoas que desconhecem os parques na Cidade de Manaus e confundem a caracterização e identidade de um parque; foi apontado que a segurança e resíduos nas trilhas são os principais aspectos negativos que precisam ser melhorados; visitam com pouca frequência os parques da cidade e por fim, gostariam de praticar outras atividades de lazer, nem sempre compatíveis com a realidade de cada parque em Manaus.

Palavras-chave: Meio ambiente; educação ambiental; percepção ambiental; parques urbanos; Manaus.

\begin{abstract}
The theme of "environment", nowadays, are increasingly being embedded in society. The natural environment has been replaced by urban spaces, and these stages of relationships between the human community and its physical environment. Urban space is composed of a range of variations of uses, including residential, commercial, industrial, recreational, urban parks, among others. Even with so many environmental and social benefits, green spaces have not been a priority use in urban space. The company admits that appropriate environmental conditions is crucial in the use of these areas, contributing to the promotion of health and wellness. In this sense, the present study aimed to analyze the environmental perception of students on urban parks Manaus, aiming to better understand their needs directed to the welfare, recreation, leisure, etc. A questionnaire with 18 questions was administered to 110 respondents. At the end of the analysis can be seen that some terms and environmental situations are still not clear to respondents, not all respondents have interest in activities and environmental practices, demonstrating a low level of importance, there is a small portion of people who are unaware of parks in the city of Manaus and confuse the identity and characterization of a park, it was pointed out that safety and waste on the trails are the main negative aspects that need to be improved; visit infrequently city parks and eventually would like to practice other leisure activities, not always compatible with the reality of each park in Manaus.
\end{abstract}

Keywords: Environment; environmental education; environmental perception; urban parks; Manaus. 


\section{INTRODUÇÃO}

O grande desafio da sustentabilidade urbana reside na capacidade de tratar as cidades e o seu meio natural em sua especificidade e em toda a sua complexidade, através de uma abordagem multidimensional e interdisciplinar que permita a superação dos desequilíbrios resultantes dessas trocas desiguais, sejam elas internas ou externas à cidade (MELAZO, 2005).

Nos dias de hoje pode-se notar que cada vez mais as pessoas querem estar próximas dos centros urbanos. Segundo Silva (2003), nos últimos três séculos os habitantes das cidades têm procurado manter a satisfação emocional e inata de uma relação entre indivíduos e ambiente, estabelecida no curso da evolução humana, por meio da criação de espaços verdes.

Brouwne \& Whitaker (1973) argumentam em favor da importância das áreas verdes para melhorar a convivências dos citadinos, tal espaço seria destinado a caminhadas, encontro das pessoas, contato com ar limpo e rompimento com a rotina de trabalho ocasionando, assim, uma melhoria na saúde física e mental destes. Portanto, para RIBEIRO (2000) essas funções dos espaços verdes contribuiriam para a sustentabilidade urbana, pois geraria o melhoramento social e ambiental na cidade.

O espaço urbano é composto por uma gama de variações de usos, entre eles habitacionais, comerciais, industriais, recreativos e outros. Mesmo diante de tantos benefícios ambientais e sociais, os espaços verdes não têm sido um uso prioritário no espaço urbano. A escolha por um tipo de uso vai depender de aspectos como: prioridades de políticas de zoneamento urbano, especulação imobiliária, ações pontuais de atores urbanos, entre outros (SILVA, 2003).

Para Hildebrand (2001), o planejamento e a implantação de áreas verdes urbanas também devem considerar as características, as necessidades e opiniões da população pré e pós-inauguração, e os objetivos ou funções de cada área em relação a estes aspectos. Segundo a autora, estes procedimentos colaboram para ajustar função e uso, podendo se tornar eficientes ferramentas para o planejador na busca de uma melhor qualidade destes espaços.

Na relação entre ambiente e qualidade de vida, admite-se o conceito de ambiente como sendo o espaço onde ocorrem as ações humanas, composto por suas dimensões físicas, sociais e culturais. Neste sentido, pode-se considerar e buscar entender como o ambiente influencia positiva e/ou negativamente, o comportamento de um estilo de vida saudável, para possibilitar uma intervenção mais efetiva na criação de ambientes desejáveis e propícios para o desenvolvimento da atividade física e do lazer (REIS, 2001). A qualidade ambiental é um importante indicador de qualidade de vida (PEREIRA, 2003).

Neste âmbito, alguns estudos mostram que a boa qualidade social e física de parques urbanos, como por exemplo, infraestrutura adequada, segurança, facilidade de acesso, baixa poluição, e outros fatores positivos, aumentam a possibilidade de frequência das pessoas (REIS, 2001).

Logo, ter condições ambientais adequadas é determinante na utilização de parques, o que pode contribuir na promoção da saúde e bem estar. Em contrapartida, a má qualidade do ambiente e a insatisfação dos usuários são determinantes ambientais negativos para o uso dos parques, de forma a vir descaracterizar estas funções associadas à qualidade de vida e saúde pública.

Não basta apenas criar e distribuir reservas ambientais - como os parques urbanos-, mas deve-se atentar que seu objetivo maior é formar cidadãos conscientes e sensibilizados às questões ambientais, tanto locais quanto globais. O elo homem-meio ambiente exige responsabilidades; logo, o homem como integrante, deve sugerir e desenvolver atitudes necessárias para a conservação do conjunto de recursos naturais e patrimoniais que os cerca.

Desta forma, o estudo da percepção ambiental torna-se oportuno para que possamos compreender melhor as inter-relações entre o homem e o ambiente no qual vive, suas expectativas, satisfações e insatisfações, valores e condutas, como cada indivíduo percebe, reage e responde diferentemente frente às ações sobre o meio. $\mathrm{O}$ estudo deve buscar não apenas o entendimento do que o indivíduo percebe, mas também promover a sensibilização, a consciência, bem como o desenvolvimento do sistema de compreensão do ambiente ao seu redor. Essa ferramenta de pesquisa é fundamental para os gestores públicos para que estes possam gerar subsídios para implementação de políticas e programas que envolverão a sociedade.

Neste sentido, considerando que os parques urbanos contribuem para a qualidade de vidas dos manauaras e conservação do meio ambiente, o presente trabalho tem por objetivo investigar e compreender os atributos da percepção - interesses, necessidades e motivação de um grupo de alunos de um curso de formação técnica profissional sobre os parques urbanos da Cidade de Manaus, buscando, 
posteriormente, propiciar a integração entre homem/meio ambiente.

\section{MATERIAL E MÉTODOS}

O presente trabalho utilizou como modalidade de pesquisa, o estudo de caso. O estudo de caso é uma caracterização abrangente para designar uma diversidade de pesquisa que coletam e registram dados de um caso particular ou de vários casos a fim de organizar um relatório ordenado e crítico de uma experiência, ou avaliá-la analiticamente, objetivando tomar decisões a seu respeito ou propor uma ação transformadora (CHIZZOTTI, 1998).

Segundo Candiani et al. (2004), esta metodologia é um procedimento na qual a informação é coletada de forma sistemática e direta através de entrevistas e/ou questionários. Esta técnica é utilizada para a identificação de fatores que predispõe as motivações de um grupo, impulsionando ou restringindo suas atitudes.

O questionário elaborado continha questões objetivas e subjetivas. A utilização do questionário semi-estruturado se apoiou na referência de Whyte (1978) que considera que questões fechadas, em um estudo de percepção, permitem avaliar as experiências, as características individuais e coletivas de determinados grupos, bem como as tomadas de decisões destes. As questões abertas complementam as informações obtidas através das questões estruturadas, fornecendo informações sobre a identidade dos indivíduos e a percepção sensorial dos mesmos. As questões foram elaboradas para se obter as seguintes informações: utilização dos parques urbanos de Manaus, relação com os parques, percepção dos problemas e importância dos parques para o frequentador.

O estudo foi realizado junto aos alunos dos cursos de formação profissional do SEST/SENAT (Serviço Social do Transporte / Serviço Nacional de Aprendizagem do transporte), instituição selecionada tendo em vista o fácil acesso e por esta possuir, nas grades curriculares de seus cursos, módulos que contemplam as questões ambientais com carga horária expressiva. Tais cursos fazem parte do Programa Nacional de Acesso ao Ensino Técnico e Emprego - PRONATEC, criado pelo Governo Federal, em 2011, objetivando ampliar e democratizar a educação profissional e técnica, através do aumento do número de vagas, ampliação de instituições pelo país e bolsa de estudos aos interessados. Nesta modalidade podem se inscrever alunos cursando o ensino médio, beneficiários do seguro-desemprego e dos programas de inclusão produtiva do governo federal (como o "bolsa família") e demais interessados em cursos de capacitação.

A anuência da pesquisa foi concedida via coordenadoria da instituição, representada pela assinatura de um ofício de autorização. Os alunos que aceitaram participar da pesquisa não se identificaram no questionário, conferindo imparcialidade nominal e resguardando os direitos autorais dos mesmos.

As questões foram ordenadas em sequência lógica, objetivando caracterizar o perfil socioeconômico dos entrevistados, seu conhecimento acerca de conceitos relacionados à conservação ambiental, bem como sua percepção em relação aos parques urbanos.

Para o cálculo da amostragem foi estabelecido um nível de confiança de $95 \%$, onde o erro admitido é de apenas $5 \%$. O número mínimo representativo para a população foi de 110 elementos, considerando uma população de 450 alunos frequentadores dos cursos.

Para estipular o plano amostral da pesquisa e determinar a representatividade estatística de uma parcela da população a ser entrevistada, foi utilizada a equação de Triola (1999):

$$
n=\frac{\delta^{2} p \cdot q \cdot N}{e^{2}(N-1)+\delta^{2} \cdot p \cdot q}
$$

Onde: $n$ é o tamanho da amostra, $\delta^{2}$ é o nível de confiança escolhido, $p$ é a probabilidade de o fenômeno ocorrer, $q$ é a probabilidade complementar, $N$ é o tamanho da população e $e$ é a probabilidade de ocorrência de erro. Como os valores de $p$ e $q$ não são conhecidos usa-se atribuir o valor de 0,5 para as duas variáveis. O tamanho da amostra é de 450 alunos. Para se obter um índice de $95 \%$ de confiança, utiliza-se o valor de 1,96 (tabelado). E, por fim, utiliza-se o erro de 0,05 , devido ao fato de o índice de erro ser de $5 \%$. 
Sendo assim, obteve-se uma amostra de 110 alunos entrevistados, o que representa $24,45 \%$ dos alunos matriculados. Os dados foram analisados e sistematizados em Figuras, dispostos por frequência de respostas ou categorias.

\section{RESULTADOS E DISCUSSÃO}

Com relação ao nível de escolaridade, predominantemente nota-se que a participação maior foi de entrevistados que possuem o ensino médio completo, com $45 \%$, sendo quase a metade dos alunos. Esta informação também foi observada no levantamento feito pelo IBGE, em 2012, onde cerca de $45 \%$ dos brasileiros encontram-se na classificação de concluintes do ensino médio ou com curso superior completo. Sendo seguida por aqueles com ensino médio incompleto, com $25 \%$ to total, seguido dos de superior incompleto com $15 \%$ das entrevistas.

Abaixo são apresentados os valores para cada nível de escolaridade (Figura 1).

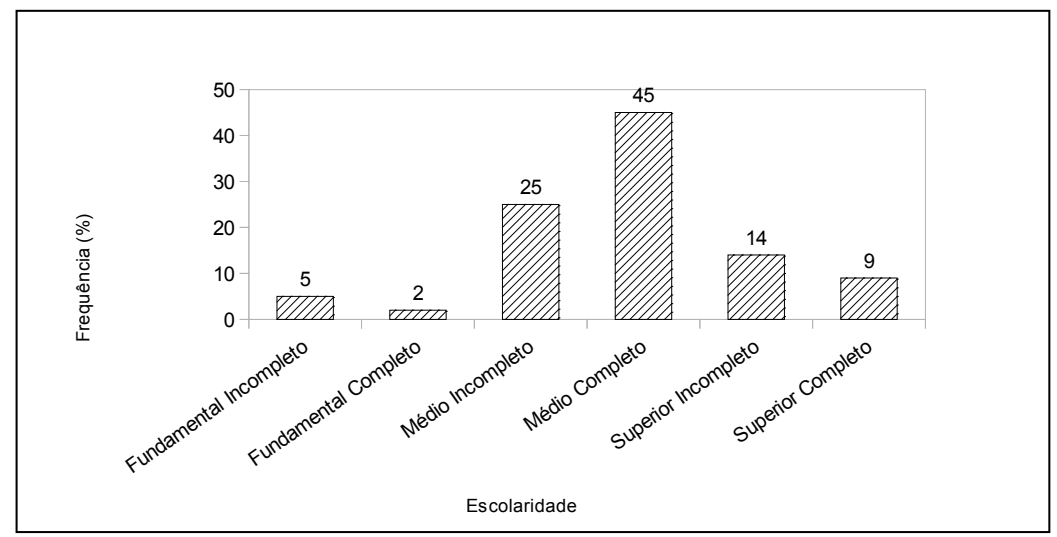

Figura 1. Escolaridade dos participantes da pesquisa.

Um fato importante que podemos notar é que as classes de alunos com apenas ensino fundamental incompleto e completo foram menores em relação às demais, $5 \%$ e $2 \%$ respectivamente. Isso mostra uma pequena evolução e diferenciação do cenário do restante do país; lembrando que talvez o cenário da população que reside nos municípios interiores do Amazonas pode ser diferente deste, já que o acesso ao ensino escolar é mais difícil.

Quando indagados sobre seu interesse pelas questões ambientais, notamos que 95\% dos entrevistados afirmaram que possuem sim interesse por questões relacionadas ao meio ambiente (Figura 2).

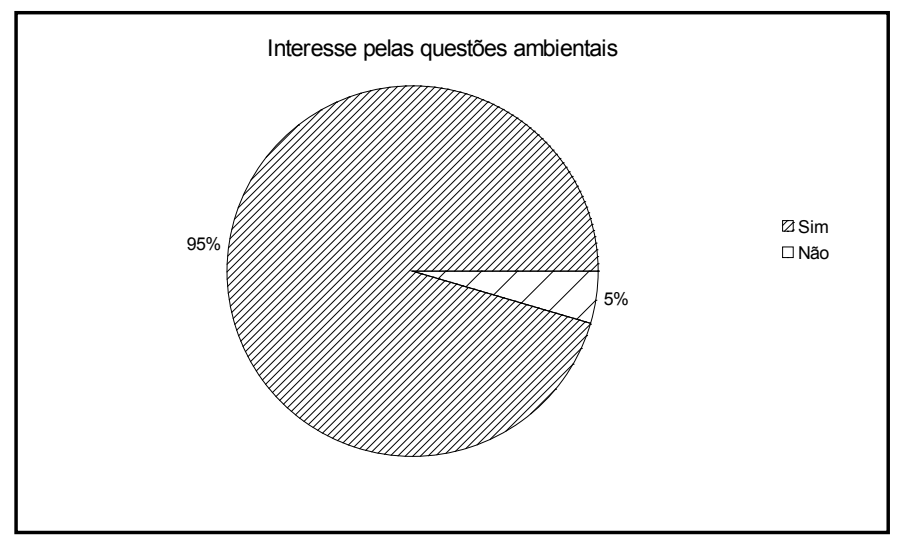

Figura 2. Interesse dos participantes pelas questões ambientais. 
Mesmo apresentando quase que unanimidade dos entrevistados em declarar seu interesse pelas questões ambientais, ainda $5 \%$ afirmou não possuir interesse por tais questões. Talvez estas pessoas ainda não estejam sensibilizadas sobre o que é realmente o meio ambiente, pois tudo a nossa volta faz parte do ambiente; o homem precisa se sentir parte também disso.

Machado (1999) afirma que todo ser humano é parte da comunidade dos seres vivos do planeta. Esta comunidade se liga com o restante da natureza e com todas as outras sociedades humanas direta ou indiretamente. Assim, cada um de nós torna-se responsável por seu próprio impacto sobre a natureza e sobre os outros seres vivos. É por isso que a criação de uma ética para a vida sustentável é indispensável, por que as pessoas agem de acordo com aquilo que acreditam e aceitam. Uma ética define direitos e responsabilidades. Uma ética para uma vida sustentável baseia-se na confiança de que as pessoas são uma força criativa e no valor de cada indivíduo e de cada sociedade. A transição para sociedades sustentáveis exigirá mudanças na forma como as pessoas percebem umas às outras, outras vidas e o próprio planeta Terra, como avaliam suas necessidades e prioridades e como se conduzem no meio ambiente.

Ferramentas de educação ambiental são usadas com o objetivo de aumentar o interesse popular nas questões ambientais e de conseguir a incorporação de práticas ambientalmente corretas no quotidiano da sociedade. Entretanto, é comum que se empreguem tais ferramentas apenas para fornecer informações sobre assuntos relativos ao meio ambiente. Esse tipo de informação realmente conseguiu incorporar o tema sustentabilidade de modo intenso nos discursos de governos, organizações nãogovernamentais, empresas e população em geral (ADGER et al., 2001). Todavia, apesar da retórica da sustentabilidade, não há evidências de que uma mudança de comportamento ampla tenha sido conseguida. A razão disso talvez seja porque retórica e apelos generalizados atuem distanciando o público da participação em ações práticas em favor do meio ambiente, já que as informações ambientais apresentadas são incorporadas na consciência discursiva do indivíduo, mas não no seu modo de vida (MYERS; MACNAGHTEN, 1998). A possibilidade de mudança comportamental ocorre quando o indivíduo faz conexões entre a informação fornecida sobre os problemas ambientais gerais e os impactos de suas práticas e hábitos diários, usando a sua própria experiência para discutir os padrões de produção e consumo (HOBSON, 2003).

Outros fatores contribuem para que a sociedade, de modo geral, tenha pouca preocupação em exibir um comportamento ambientalmente responsável ou apropriado. Essa apatia, com baixa disposição em refletir sobre hábitos, falta de interesse no engajamento político em geral, e na participação em ações coletivas ambientais especificamente, pode ser creditada a vários fatores. Macnaghten (2003) cita a falta de confiança nos governos e em outras instituições, a incompatibilidade entre a escala temporal do processo político e a do processo ambiental, e o reconhecimento, pelas pessoas, de que assuntos ambientais são mais complexos e incertos do que o considerado anteriormente.

Quando perguntados sobre o nível de importância sobre as questões ambientais, quase 80\% dos entrevistados julgaram as questões ambientais como muito importantes, com mostra a Figura 3.

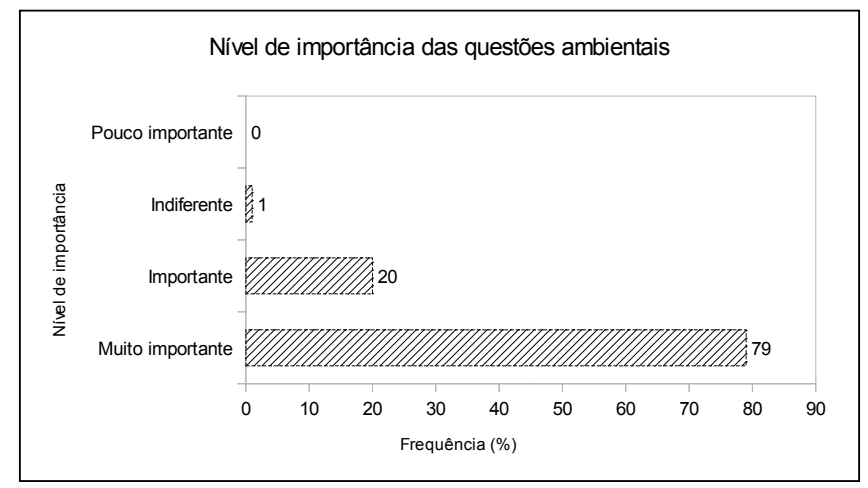

Figura 3. Nível de importância das questões ambientais para os entrevistados.

Uma parcela ainda dos entrevistados (20\%) julgaram apenas como sendo importante. Isso mostra que mesmo as pessoas não sabendo explicar a ocorrência dos fenômenos, ou como ocorrem as interações ambientais na natureza ou ainda sendo pouco sensibilizadas para as questões ambientais, ainda assim é quase unanimidade em afirmar que atentar para tais fatos são importantes e podem 
influenciar no dia a dia de cada um.

Talvez hoje em dia seja difícil estarmos sensibilizados para esta questão porque vivemos na cidade, tendo pouco contato a natureza. Em tempos passados próximos, a maior parte da população morava na zona rural e sentia na pele a importância do meio ambiente para suas vidas. Um simples fato destes cultivarem e precisarem de água para seus plantios mostrava a dependência dos recursos naturais; hoje em dia como compramos a nossa comida no supermercado e a água chega às nossas casas pelos dutos, acabamos nos esquecendo que tudo o que comemos e bebemos vem da natureza.

Nossos alimentos precisam ser plantados e cultivados pelo homem do campo antes de chegar ao supermercado. A proteína animal que consumimos também depende de um meio ambiente equilibrado. Se há grandes secas, ou chuvas em excesso, o crescimento regular das plantas fica comprometido, a produção dos alimentos diminui, tornando-se insuficiente para alimentar toda população. Se há pouca comida, os preços sobem, ou seja, é uma questão não apenas ecológica e sim puramente econômica.

No objetivo de começar a conduzir a entrevista para avaliação da percepção sobre os parques de Manaus, foi perguntado aos entrevistados se estes saberiam dizer se em Manaus existem áreas de recreação que proporcionem contato com a natureza (parques e unidades de conservação, etc.). $\mathrm{O}$ resultado é mostrado na Figura 4.

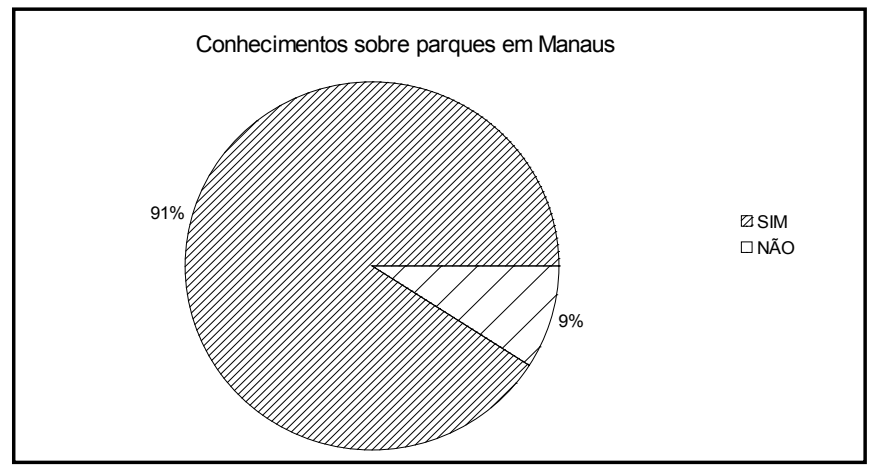

Figura 4. Conhecimento sobre a existência de parques ou áreas verdes na Cidade de Manaus.

Como esperado, mais de $90 \%$ dos entrevistados afirmaram que sim, que existem parques ou áreas verdes na Cidade de Manaus que proporcionem o contato com a natureza. Uma pequena parte dos entrevistados declararam não saber se existem tais áreas. Mesmo com a intensificação de programas de educação ambiental divulgados nos meios de comunicação (rádio, televisão, internet e rede sociais) e nas escolas, ainda assim alguns desconhecem essas áreas. Isto implica em dizer que estes nunca visitaram um parque ou área verde na Cidade, deixando de usufruir dos benefícios que o contato com o meio ambiente pode proporcionar.

Dentre os que sabem que existem e conhecem estas áreas na cidade, foi perguntado quais os parques que eles já visitaram ou que apenas conhecem de ouvir falar (Figura 5).

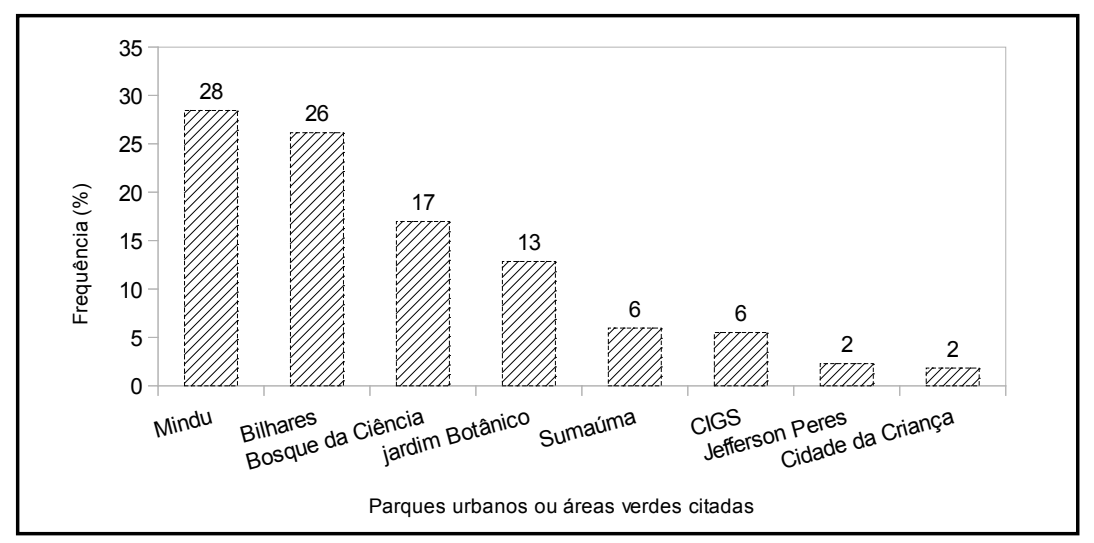

Figura 5. Parques ou áreas verdes apontados pelos entrevistados. 
O destaque é maior para o Parque do Mindu, onde $28 \%$ dos alunos já o visitaram, seguido também por pouca diferença do Parque dos bilhares, com $26 \%$ das indicações. Em se tratando de um parque com bastante área verde a maioria da população manauara aponta o Mindu, pois já possui alguns anos de existência na Cidade e grande parte das ações de educação ambiental junto às escolas são realizadas nele. Já o parque dos bilhares é um parque que não possui uma área verde tão densa tanto quanto ao do Mindu e outros que estão mais atrás na escala gráfica, como Jardim Botânico Adolfo Ducke e Sumaúma, sendo mais voltado para o lazer e entretenimento esportivo dos cidadãos que o frequentam.

Como mostrado na Figura 5, existem alguns outros nomes citados que não cabem na categoria de parque, mas que, entretanto foram citados na entrevista, como o Bosque da Ciência e o Zoológico do CIGS, que apesar de possuírem uma área verde, não são considerados parques. Desta forma, cabe aqui, apontarmos a definição de parques e áreas verdes urbanas, como segue:

Segundo o Ministério do Meio Ambiente do Brasil (MMA), "parque urbano" é uma área verde com função ecológica, estética e de lazer, no entanto, com uma extensão maior que as praças e jardins públicos.

As áreas verdes de uma cidade incluem todos os espaços que possuem cobertura vegetal natural ou implantada, como as áreas de preservação permanente, parques públicos, praças e áreas verdes destinadas à recreação pela legislação competente. Para tanto, sua abrangência engloba os espaços públicos e privados (ABREU, 2004). Ma estão são inclusas como Unidades de Conservação.

Observamos que, o Parque Jefferson Peres, por estar situado na Zona Sul de Manaus, recebeu menos destaque, considerando que, como a maioria dos entrevistados residem nas zonas Leste e Norte, estes não visitam ou procuram áreas mais distantes para visitarem. Outro fator também remete-se a sua inauguração ser relativamente recente, datando de 2009, tendo apenas 5 anos de existência.

O Parque Cidade da Criança criado também recentemente pela Prefeitura Municipal de Manaus, também não é muito conhecido pela população entrevistada, devido provavelmente às suas programações, que são voltadas inteiramente para crianças, abrangendo um público-alvo bem menor. O Parque Lagoa do Japiim e o Nascente do Mindu sequer foram mencionados ou lembrados pelos entrevistados; talvez seja pela sua pequena área que possui em relação aos demais existentes na cidade ou talvez por não ter em uma atratividade de atividades que possam ser desenvolvidas. De todos, Mindu, Bosque da Ciência, Ducke, Sumaúma e CIGS (zoológico) são os que dedicam-se às atividades no âmbito da educação ambiental na cidade.

Para alguns entrevistados o conceito de parque ou mesmo área verde ainda encontra-se desorganizado, uma vez que houveram apontamentos sobre nomes de parques de diversões no questionário; isso mostra que muitos não possuem conhecimento sólido sobre as questões ambientais mínimas.

Quando perguntados sobre qual a serventia dessas áreas na cidade, observam-se os seguintes resultados (Figura 6):

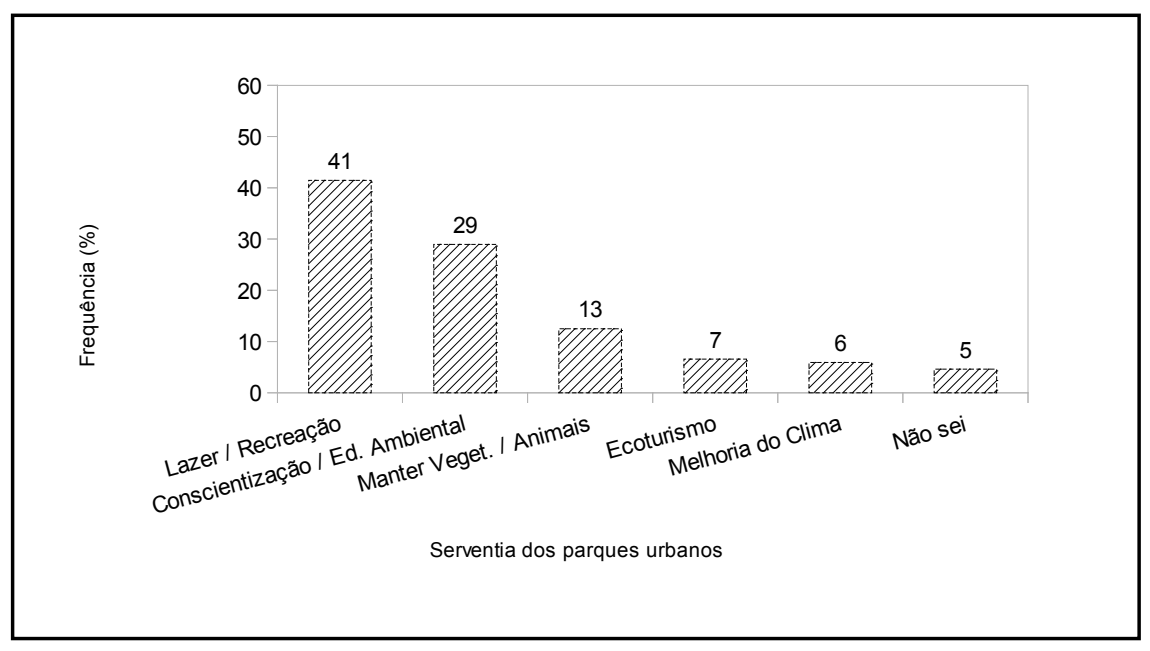

Figura 6. Serventia dos parques urbanos ou áreas verdes na Cidade de Manaus. 
A maioria dos entrevistados optou por dizer que estas áreas servem lazer e recreação. Neste contexto analítico, Loboda e Angelis (2005) afirmam que as áreas verdes urbanas contribuem para a melhoria da qualidade de vida urbana. Gomes (2005) complementa a afirmação de Nucci (2008), apontando que as áreas verdes, "do ponto de vista psicológico e social, influenciam o estado de ânimo dos indivíduos massificados com o transtorno das grandes cidades".

Em segundo lugar com mais apontamentos aparece a opção que diz que estas áreas servem para "conscientização e educação ambiental" e manter a vegetação e os animais protegidos. O fato é que todas as opções compõem o verdadeiro uso e objetivo destas áreas existirem na cidade, conforme citado por Nogueira e Wantuelfer (2002), onde afirmam que áreas verdes sejam utilizadas com objetivos sociais, ecológicos, científicos ou culturais.

Troppmair e Galina (2003) acrescentam, enfatizando as vantagens das áreas verdes:

a) Criação de microclima mais ameno que exerce função de centro de alta pressão e se reflete de forma marcante sobre a dinâmica da ilha de calor e do domo de poluição;

b) Despoluição do ar de partículas sólidas e gasosas, dependendo do aparelho foliar, rugosidade da casca, porte e idade das espécies arbóreas;

c) Redução da poluição sonora, especialmente por espécies aciculiformes (pinheiros) que podem acusar redução de 6 a 8 decibéis;

d) Purificação do ar pela redução de microorganismos;

e) Redução da intensidade do vento canalizado em avenidas cercadas por prédios;

f) Vegetação como moldura e composição da paisagem junto a monumentos e edificações históricas.

Pode-se constatar que ainda 7 pessoas afirmaram que não sabem qual serventia tem essas áreas.

Quando perguntados se já haviam visitado um parque, reserva ou unidade de conservação em Manaus, $83 \%$ dos alunos afirmaram que sim, que já visitaram (Figura 7).

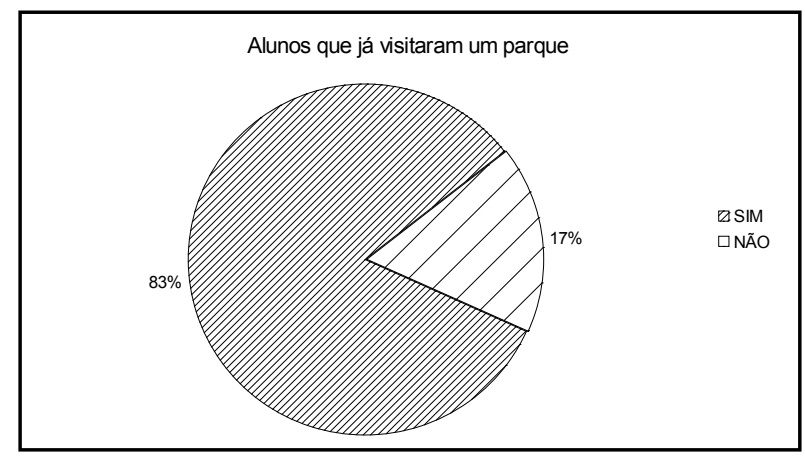

Figura 7. Porcentagem de entrevistados que já visitaram um parque.

Cerca de 27\% (19 entrevistados) declararam que nunca visitaram um parque, o que é um dado um tanto preocupante no contexto existente na sociedade atual, julgando-se desta forma, importante saber o "motivo" da não visita.

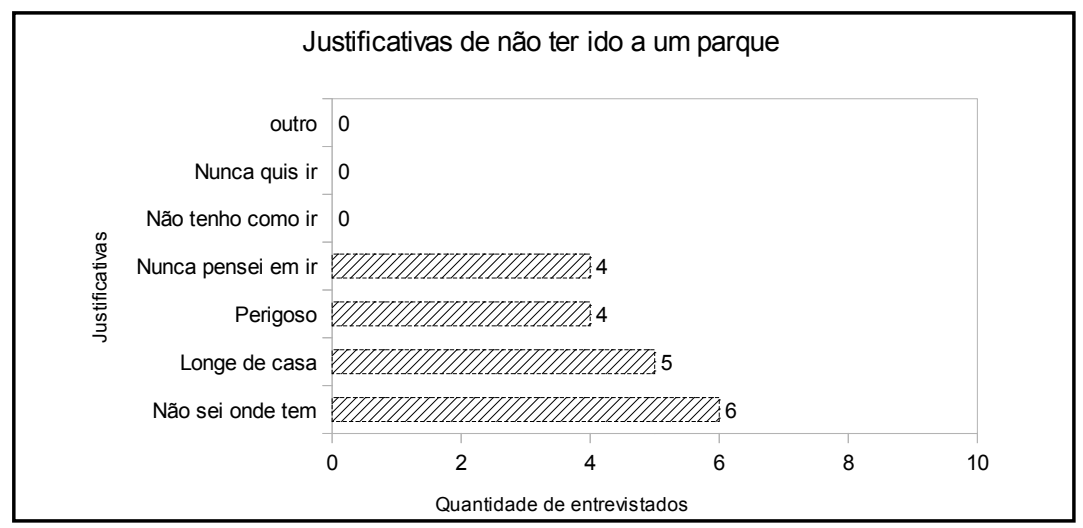

Figura 8. Justificativas dos entrevistados que nunca foram a um parque em Manaus. 
"Não saber onde tem" e "ser longe de casa" foram as justificativas mais abordadas por parte de quem nunca foi a um parque na Cidade de Manaus. Infelizmente Manaus carece de um guia ambiental onde estivesse inserido um mapa que destacasse essas áreas destinadas ao lazer e recreação natural. Alguns destes parques ficam em áreas distantes; mesmo assim, isso não pode ser considerado como empecilho pois parques como o Sumaúma, Jardim Botânico e Nascentes do Mindu situam-se nas zonas norte e leste, respectivamente.

Existe ainda o fator segurança, que foi também abordado. Muita gente. Algumas pessoas ainda tem uma visão de que área verde só serve para abrigo e mal uso de marginais e viciados, que usam o local para drogarem-se e fazerem assaltos.

Outro fator que deve entrar em discussão também possa ser a inversão dos valores relacionados à lazer e recreação. Em Manaus há uma grande concentração de outros espaços que também oferecem lazer (como shopping centers, cinemas, teatro, dentre outros), talvez as pessoas estejam frequentando mais tais lugares. Obvio que cada um tem sua particularidade e forma de entretenimento diferente, mas devido à aversão aos que chamam de "mato", julga-se interessante fazer tal ressalva.

Quanto aos que possuem a prática de usar essas áreas, perguntou-se a frequência de visita em tais áreas, como mostrado na Figura 9:

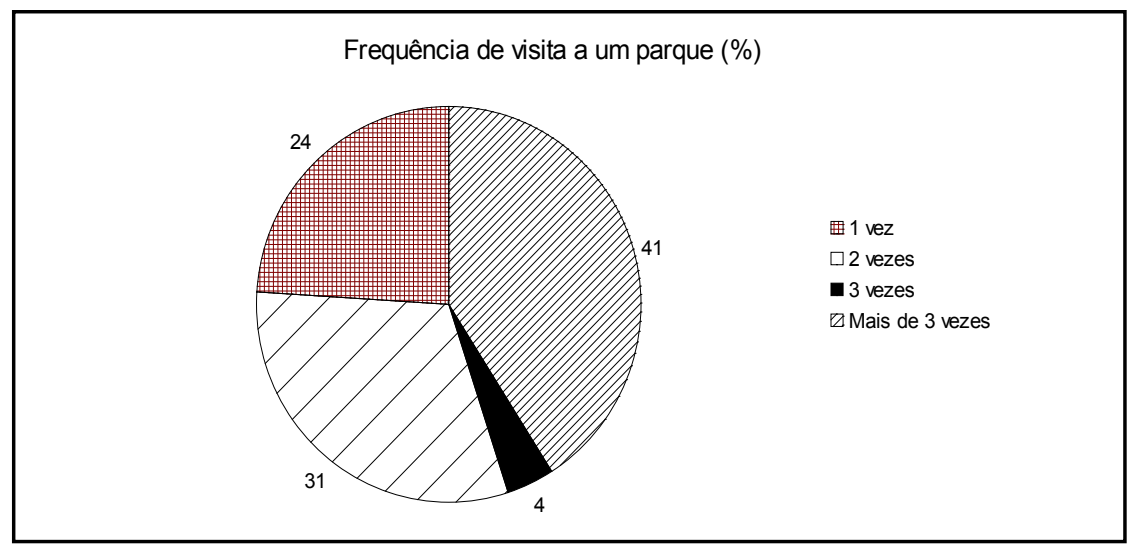

Figura 9. Frequência de visita a um parque.

Notoriamente, cerca de $40 \%$ dos entrevistados já visitaram mais de três vezes os parques de Manaus, seguido dos que visitaram apenas duas vezes, com cerca de $30 \%$ dos apontamentos. Apenas $4,4 \%$ dos entrevistados visitaram três vezes um parque; tal número é considerado baixíssimo, se dividirmos pela proporção entre os meses do ano. Isso significa dizer que as pessoas que apontaram este número, visitaram um parque quadrimestralmente.

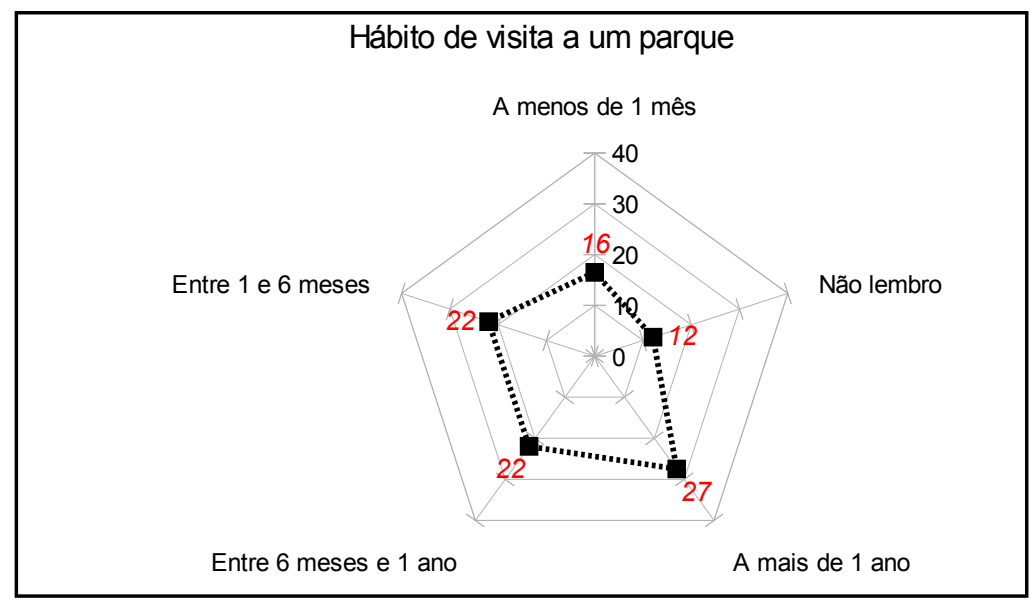

Figura 10. Hábito de visitar um parque entre os entrevistados. 
A Figura 10 mostra claramente que os entrevistados demoram bastante tempo para fazer uma visita a um parque. Percebe-se que $27 \%$ dos entrevistados visitaram um parque a mais de um ano e $22 \%$ faz mais de 6 meses que não visita. Apenas uma pequena parcela dos entrevistados (16\%) visitaram um parque a menos de um mês da entrevista. Esse dado é importante, pois mostra que mesmo com a existência dos parques a população não está se sentindo atraída para visitá-los.

Esta frequência de visita nos parques ainda é fora da realidade de muitos países da Europa. Em uma pesquisa realizada em Portugal a frequência de visita tem intensidade semanal, como mostrado na Figura 11.

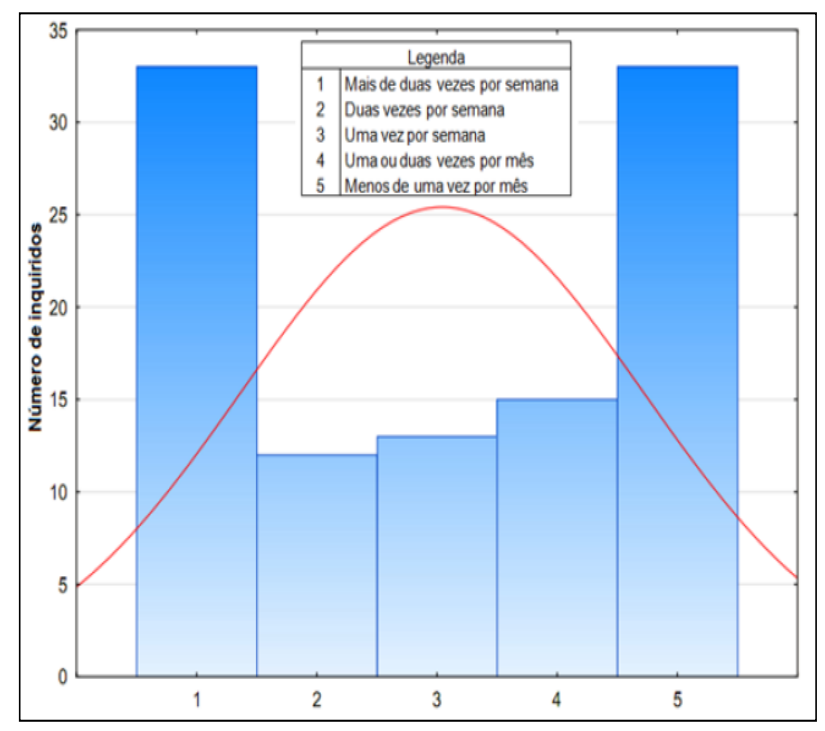

Figura 11. Frequência de visita em um parque urbano na Cidade do Porto, Portugal.

Como se pode verificar pela Figura, existem dois principais grupos de respostas: por um lado, os que visitam o Parque da Cidade do Porto mais do que duas vezes por semana ( $31 \%$ dos respondentes) e, por outro lado, os que o visitam menos de uma vez por mês (também 31\% dos respondentes), de acordo com Santos (2013).

$\mathrm{O}$ aumento no número de visitantes pode ser creditado a diversos fatores, dentre os quais, se destacam: o incremento de políticas voltadas para o turismo, com especial ênfase ao ecoturismo, o modismo em visitar unidades de conservação, amparados em valores de conscientização, de preservação e contemplação da natureza e, finalmente, com a popularização e divulgação pela mídia eletrônica, segundo Ladeira et al., (2007).

Adentrando-se nas questões específicas aos alunos que já estiveram em um parque, perguntouse qual o motivo de sua visita nessas áreas, como apresentado na Figura 12.

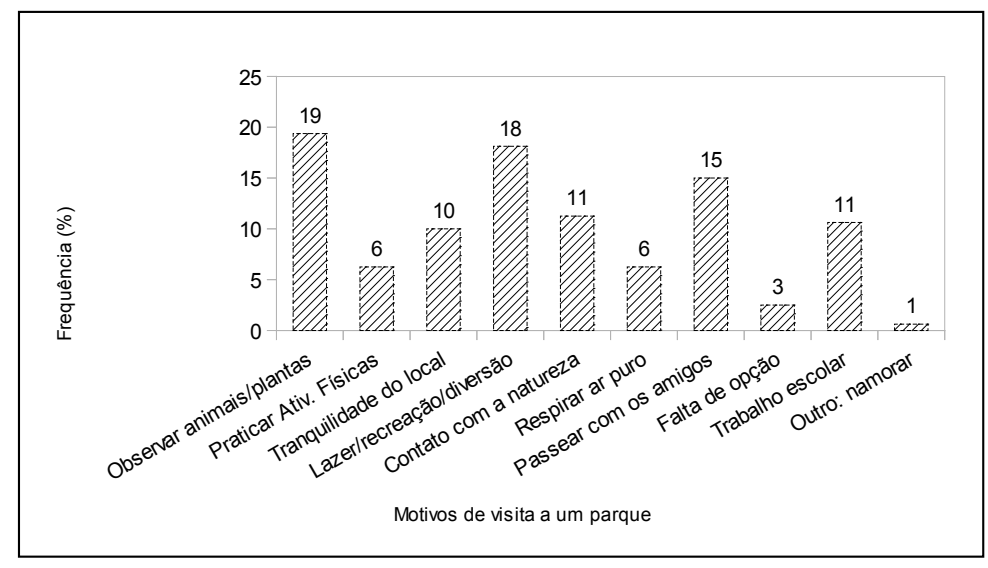

Figura 12. Motivo de visita a um parque. 
Os motivos mais destacados pelos alunos foram observação de animais e das plantas, lazer/ recreação/diversão e passear com os amigos, perfazendo 19,8\%, 28,6\% e 15,4\%, respectivamente.

Por estarmos em uma região rica em biodiversidade, esperava-se já o resultado onde as pessoas buscam conhecer um pouco mais da fauna e flora da região, principalmente nos parques que possuem trilhas interpretativas por entre a floresta. Atividades de lazer, recreação e diversão aparecem logo em seguida, pois muitos parques centrais de Manaus apresentam atividades deste cunho, destacando-se o Parque dos Bilhares e o Jefferson Peres. Parques como o Jardim Botânico Adolfo Ducke e Mindu apresentam também esta categoria de atividade, porém mesclando mais com atividades de cunho ambiental.

Em uma pesquisa realizada por Tomiazzi em 2006, mostrou que a maioria dos visitantes eram atraídos pela natureza $(40 \%)$, considerando este o fator mais atraente.

Essa realidade é similar às vividas no restante do Brasil. Silva (2003), em uma pesquisa desenvolvida em um parque urbano de Brasília obteve os seguintes dados: 76\% dos entrevistados afirmaram que um parque serve para trazer lazer à sociedade.

Nas pesquisas de Takahashi \& Martins (1990), foi colocado que os visitantes não estão em busca de facilidades recreativas e sim de relaxamento em um ambiente natural.

Costa (2010) verificou em sua pesquisa, feita no Parque Sabiá, em Minas Gerais, que quando indagados sobre a importância de se ter uma área verde na cidade as palavras que mais apareceram entre os entrevistados foram, em ordem de frequência: lazer, qualidade de vida, gratuito, acessível, saúde, ar limpo.

Os com menor representatividade estão as alternativas "falta de opção" e "namorar", sugerido como outra atividade fora das sugeridas no questionário, apresentando respectivamente $2,5 \%$ e $0,6 \%$. Tomiazzi (2006) em sua pesquisa feita em um parque natural do Rio de Janeiro constatou que $7 \%$ dos entrevistados visitaram o parque pela falta de opção de lazer. Essa declaração da falta de opção pode estar atrelada a que tais pessoas não tenham outras opções fora do contexto urbano e daí sujeita-se a visitar os parques. É interessante que em outros países ou até mesmo em alguns parques conhecidos no Brasil, as pessoas usam as dependências dos parques frequentemente para, como por exemplo, realizar piqueniques com a família. Uma minoria da população ainda não encontra-se sensibilizada para as questões sócio-ambientais.

Pouco mais de $10 \%$ dos alunos entrevistados afirmaram ir a um parque para fazer trabalhos escolares. É uma pequena porcentagem, porém tem efeito imenso para a educação ambiental, pois estas atividades estimulam o contato direto com o meio ambiente. Cabe às escolas promoverem tais tipos de programação.

Quando indagados sobre a sensação que sentiram quando estavam em um parque de Manaus, quase $50 \%$ dos entrevistados afirmaram que sentiram-se em um ambiente agradável, conforme Figura 13.

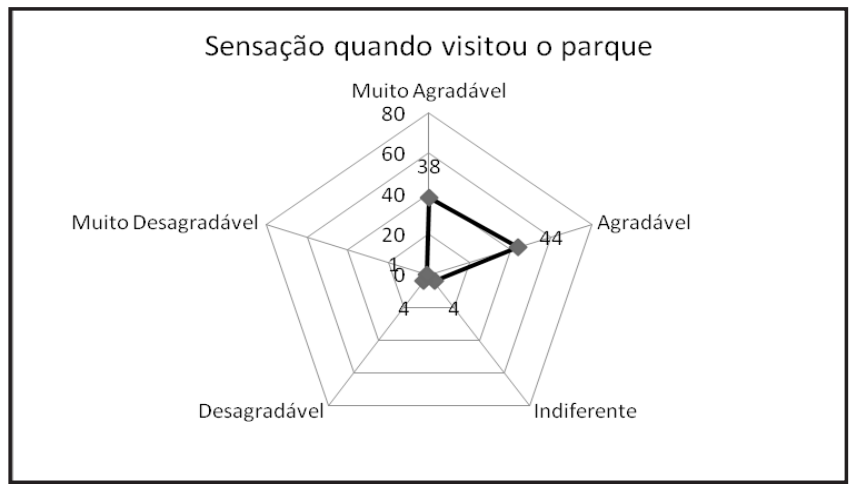

Figura 13. Sensação durante visita em um parque.

É possível visualizar um mapeamento referente às sensações que podem-se ocorrer durante uma visita observando-se a Figura 13. Considerando a leitura do centro para as extremidades, e adotando-se que no centro é o ponto inicial, permite-nos compararmos as situações entre si. Neste caso, 
os entrevistados elegeram a sensação de maior proporção como sendo a "agradável" e depois "muito agradável", ambas com 48,8\% e 41,7\%, respectivamente. Logo, a Figura mostra o destaque variando do agradável para o muito agradável, onde juntas perfazem mais de $90 \%$ da preferência dos entrevistados. Esse dado mostra o nível alto de segurança e tranquilidade com que os visitantes se depararam ao visitar um parque.

Quanto ao aspecto de segurança durante as visitas nos parques, observam-se os seguintes resultados, apresentados na Figura 14:

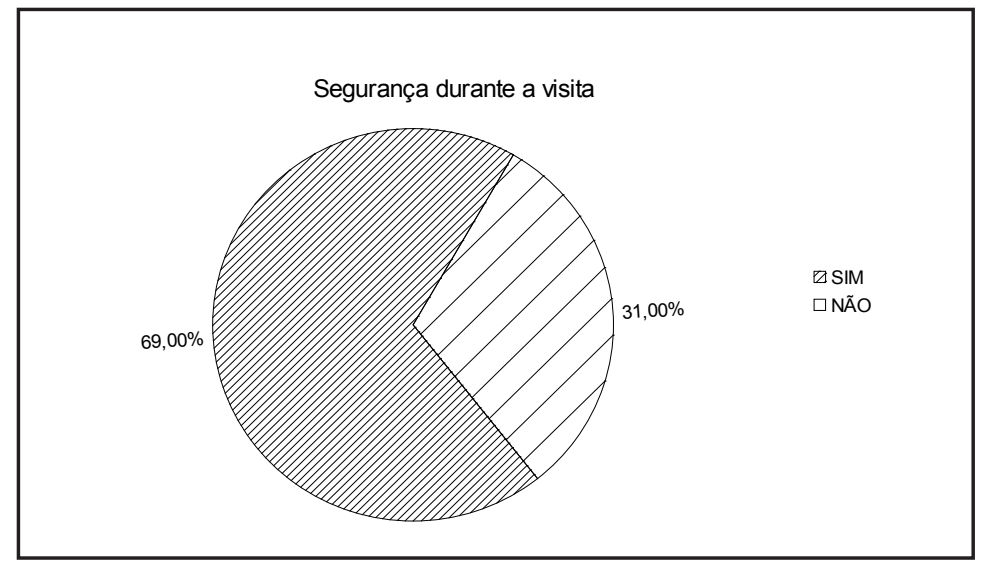

Figura 14. Segurança durante a visita nos parques.

Esse é um quesito que diz respeito à atração de fidelização de visitantes nos parques, pois se o visitante não sentir-se seguro, dificilmente retornará àquele local, uma vez que jamais colocará em risco sua própria vida ou dos que o acompanham.

Quase 70\% dos entrevistados sentiram-se seguros em suas visitas, porém há ainda uma grande parte (que perfaz 30\% dos entrevistados) que por algum motivo sentiram-se inseguros ou talvez tenham passado por alguma situação de risco. Isso pode ser atribuído, principalmente, que alguns parques da cidade possuem uma considerável área florestada, abrindo precedentes para o uso indevido destes locais para prática do uso de entorpecentes e assaltos. Nessa categoria, incluem-se os parques do Mindu, Sumaúma, Nascentes do Mindu e Jardim Botânico. Vale ressaltar que todos estes possuem seguranças de plantão e um gradio, isolando a área de floresta dos parques. Mesmo assim, isso pode não ser suficiente para afugentar marginais do local.

Recentemente, o parque Sumaúma foi invadido por desordeiros e foi gerado um enorme prejuízo aos cofres públicos, depredando as instalações e equipamentos, como mostrado pelo Instituto Ecológico e Comunitário da Amazônia (IECAM), entidade civil de direito, sem fins lucrativos, sócio-ambiental e educacional, envolvida em propostas para o pleno exercício da cidadania. A Figura 15 mostra como ficaram as instalações após a invasão:

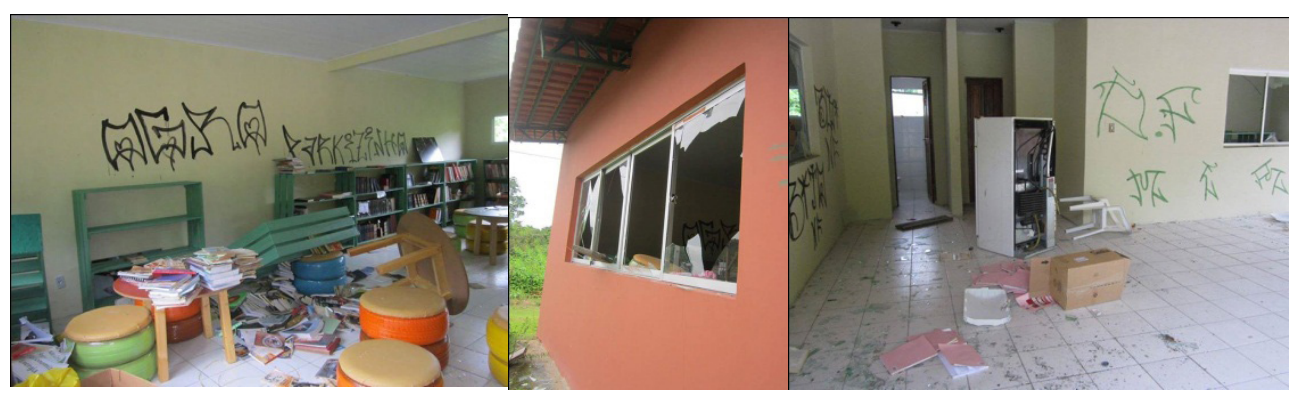

Figura 15. Depredação ocorrida no Parque Sumaúma em 2014. Fonte: IECAM (2014).

Os parques dos Bilhares, Jefferson Peres e Lagoa do Japiim também possuem segurança patrimonial e gradio de isolamento da área. Ambos possuem horário de visitação, onde o visitante pode realizar suas atividades em segurança. 
Esse aspecto é importante ser analisado, pois em outros parques do Brasil também há um cuidado especial para este detalhe. Em um parque de Uberlândia, em Minas Gerais, Moreira et al., (2011) afirmou que $10 \%$ dos entrevistados apontaram a falta de segurança como um dos fatores negativos identificados. O problema mais destacado foi o de que pessoas utilizam esses locais para se drogarem, e inclusive, já foi palco para homicídios.

Entre as medidas que podem contribuir para o aumento da segurança incluem-se o uso de câmeras de vigilância em trechos isolados dos parques, ronda de monitoramento de guardas-parque, investir na iluminação em locais mais escuros e a poda de manutenção em árvores e arbustos próximo aos locais de tráfego de pessoas.

Semelhante a isso, outro questionamento feito aos entrevistados, onde perguntava-se se durante sua visita foi percebido algum aspecto negativo, como mostra a Figura 16.

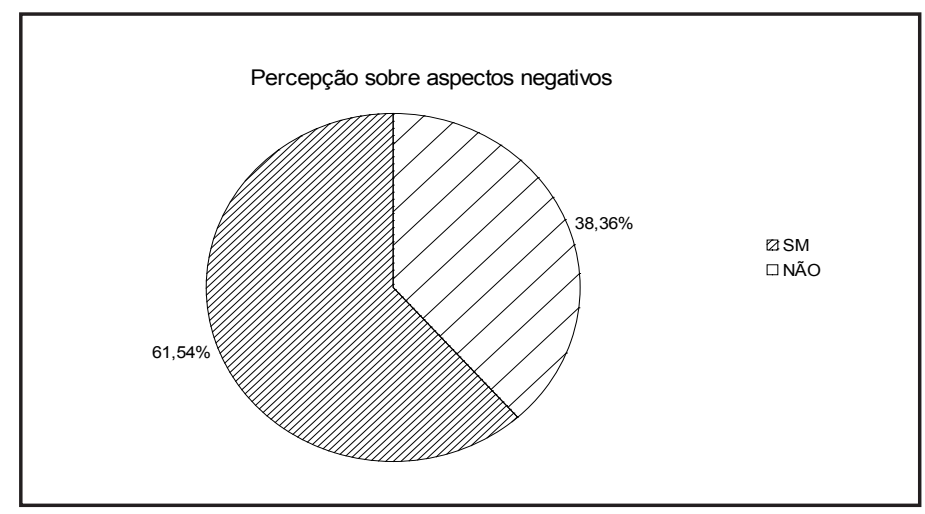

Figura 16. Percepção sobre aspectos negativos durante as visitas nos parques.

Mais de $61 \%$ dos entrevistados afirmaram que observaram aspectos negativos durante sua visita. Nota-se até que, a proporção de entrevistados que julgaram não ter aspecto negativo em consideradamente expressiva, onde quase $40 \%$ não encontrou problemas a ser destacado.

Dentre os principais problemas destacados pelos entrevistados, cita-se (Figura 17):

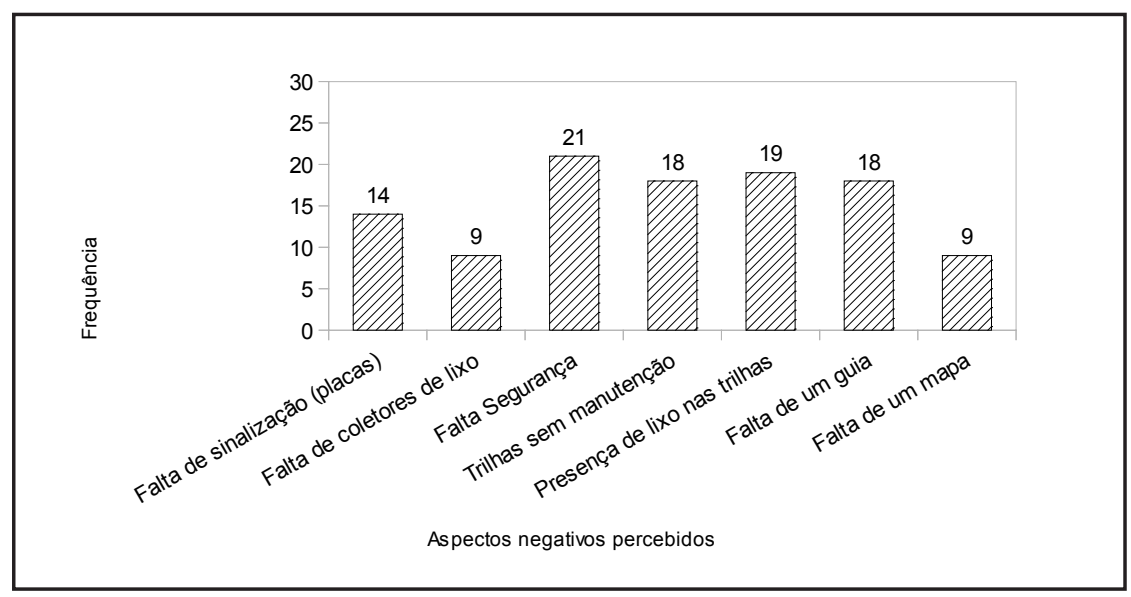

Figura 17 Problemas percebidos pelos entrevistados.

Destacam-se entre os principais problemas , a falta de segurança, como já mencionado anteriormente, a presença de lixo nas trilhas , a falta de guia e trilhas sem manutenção, ambos com 19,44\%, $17,59 \%$ e $16,67 \%$, respectivamente.

Todos os problemas merecem a atenção dos gestores dos parques, pois serve como base para auxílio na tomada de decisões e mudanças que precisam ser feitas.

É notório, em alguns parques, o estágio de degradação em que se encontram as trilhas de acesso, coletores de lixo e a sinalização (placas). 


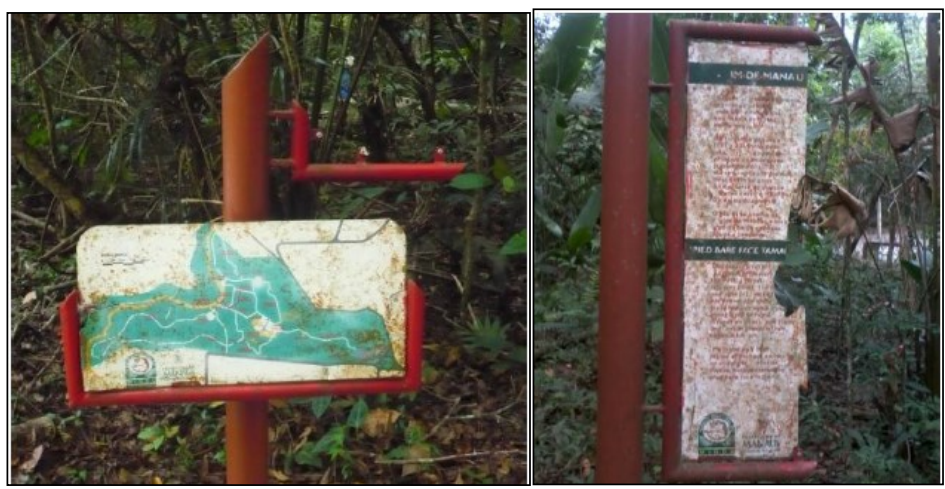

Figura 18. Grau de deterioração das placas no parque do Mindu.

Os autores ainda citam que as trilhas do Parque apresentam um alto de grau de degradação em suas bordas com as raízes da vegetação expostas, onde isso causa uma imagem negativa para o visitante e que nada remete ao ambiente natural que a área deveria proporcionar para quem a visita.

Outro aspecto que chama muito a atenção pelo seu caráter visual é o lixo nesses locais. Em específico os parques do Mindu, dos Bilhares e Jefferson Peres, que possuem igarapé cortando suas áreas, são campeões no que diz respeito ao acúmulo de lixo. As equipes de limpeza sempre estão trabalhando nesses locais, porém é constante o acúmulo, conforme mostrado na Figura 19.

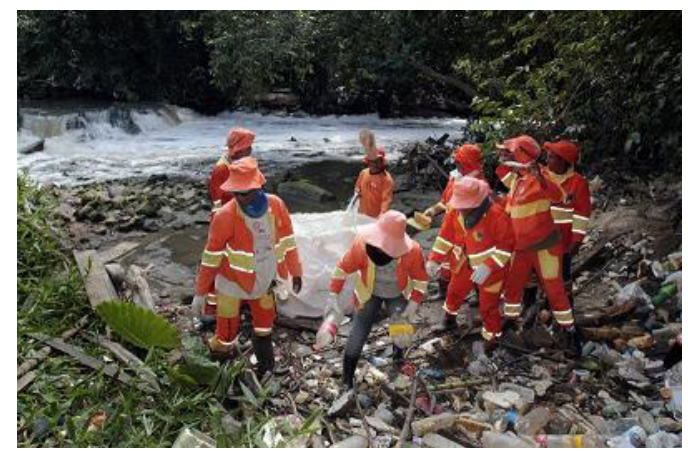

Figura 19. Equipes de limpeza fazendo remoção de lixo do igarapé do Mindu. Fonte: SEMMAS (2013).

Além da possível transmissão de doenças por meio do lixo, há ainda a proliferação de animais que vivem no meio da sujeira, como ratos e insetos, inclusive o mosquito da dengue.

O mau cheiro também afasta a presença dos visitantes, que sentem-se incomodados durante a prática de suas atividades. Talvez o odor desagradável e o comprometimento estético da paisagem sejam um dos fatores que afete e contribua para a baixa visitação nos parques.

Animais silvestres ainda dividem espaço com o lixo, apresentando risco à integridade física destes (Figura 20).

Investimentos em educação ambiental tornam-se necessários para diminuição ou erradicação desses problemas, que afetam diretamente a saúde pública de quem utiliza esses parques. A instalação
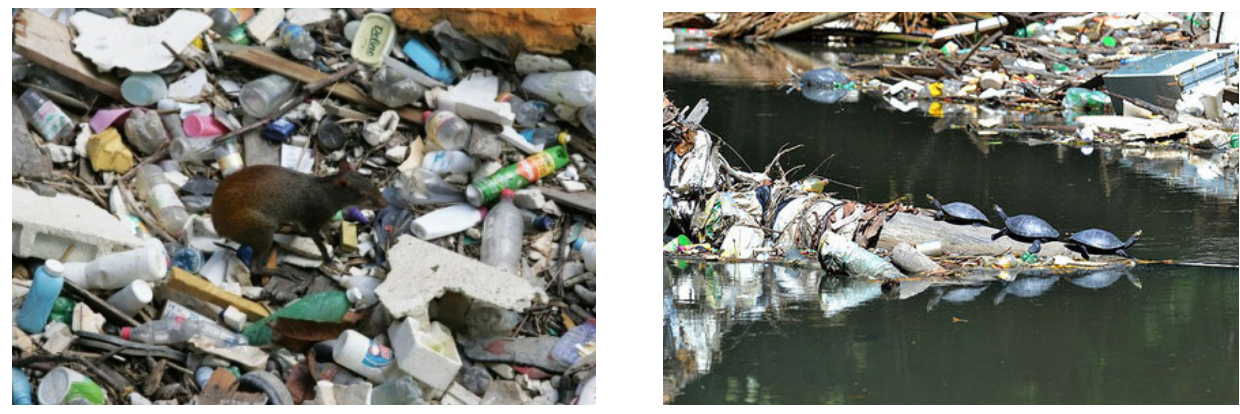

Figura 20. Animais dividindo espaço com lixo no parque do Mindu em Manaus. Fonte: Prefeitura Municipal de Manaus (2013). 
de coletores adequados para os resíduos também é uma medida preventiva para evitar o acúmulo de lixo nas trilhas.

Entre as sugestões de melhoria que obtiveram mais destaque foram segurança, serviços de alimentação e distribuição de panfletos educativos e implantação de bebedouros e banheiros, com 21\%, $14 \%$ e $13 \%$ respectivamente, conforme mostrado na Figura 21.

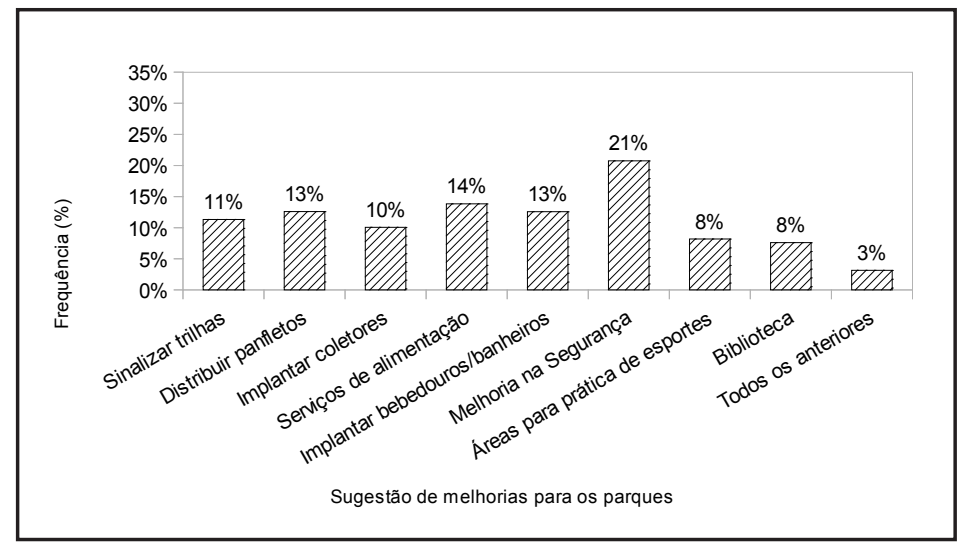

Figura 21. Sugestões de melhorias para os parques de Manaus.

Todos esses fatores, se observados pelos gestores, poderão contribuir para a maior atratividade de visita nos parques de Manaus.

De modo geral, a melhoria na infraestrutura é fundamental para que o visitante sinta aconchego. A instalação de bebedouros ou fontes é algo a ser destacado, que em alguns parques brasileiros já existe, como por exemplo, no Parque das Águas, na Cidade de São Lourenço, em Minas Gerais, oferecendo refrescância ao visitante que precisa amenizar o calor, Figura22.

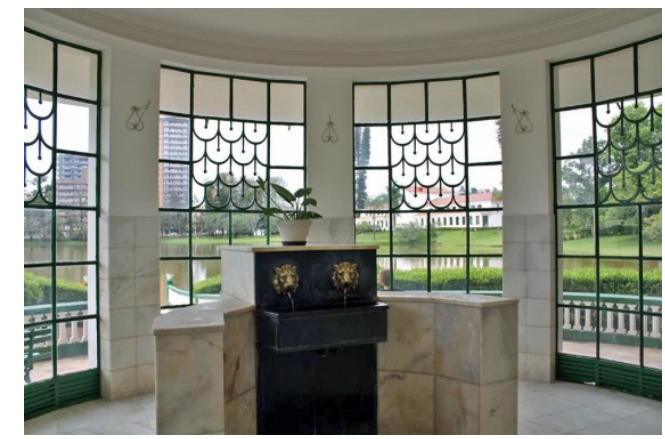

Figura 22. Fonte de água no Parque das águas em São Lourenço, MG. Fonte: Skyscrapercity (2012).

Em alguns parque de Manaus é possível também notar a presença de lanchonetes e restaurantes, visando atrair os visitantes onde desta forma este passará mais tempo nas dependências do parque. O Parque dos Bilhares possui lanchonetes e sorveteria, além da venda de guloseimas e iguarias regionais. O Parque Jefferson Peres possui espaço para lanchonetes, que infelizmente, só funcionaram no período de sua inauguração, onde segundo relatos de visitantes, tem que se deslocarem para outros locais que fornecem tal serviço. Aos domingos o parque do Mindu também dispõe de café da manhã, levando muitos manauaras a visitarem o parque para tomar café e depois realizarem um passeio pelas trilhas.

Quanto à prática de esportes, alguns parques oferecem este recurso, destacando-se entre eles o dos Bilhares. Já o parque Jefferson Peres e Lagoa do Japiim apresentam infraestrutura que permitem a prática de caminhada e corrida, possuindo trilhas com calçamento em concreto.

Quanto à biblioteca, é uma sugestão interessante, pois estimula os visitantes a fazerem pesquisa, principalmente sobre assuntos relacionados à educação ambiental. Apenas os Parques do Mindu, Bilhares, Sumaúma e Jardim Botânico dispõem de um espaço destinado a leitura.

Quando perguntados sobre quais atividades gostariam de praticar ou gostariam que tivesse em um parque de Manaus, a maioria dos entrevistados escolheram acampar (Figura 23). 


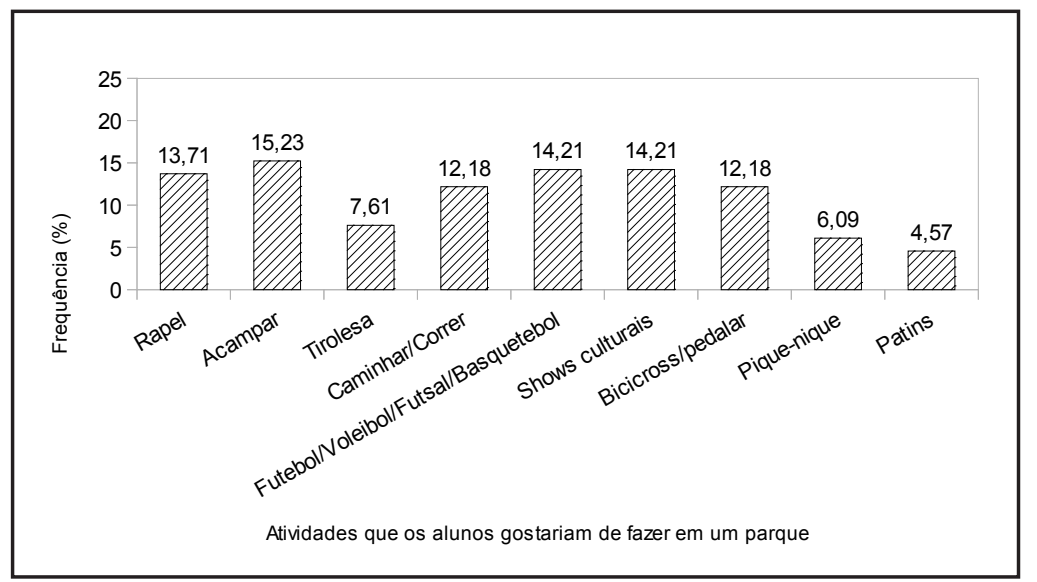

Figura 23. Atividades que os entrevistados gostariam de fazer nos parques.

Acampar é uma prática não muito comum entre os manauaras, pois não se tem o hábito entre as pessoas. Pra que isso venha ocorrer nos parques, é necessário primeiramente uma análise de viabilidade da ideia, destacando prós e contras. É notório que nem em todos os parques será possível esta prática. Apenas os com cobertura florestal poderiam oferecer tal atividade, lembrando que o fator segurança deve estar em primeiro lugar. Em outros municípios ainda mesmo no Estado do Amazonas, já funciona há algum tempo esta prática, como no caso do Município de Presidente Figueireido, só que não em parques, e sim em propriedades particulares.

Atividades como caminhar ou correr, prática de futebol, voleibol, futsal e basquetebol já é possível em alguns parques, como no Jefferson Peres, Lagoa do Japiim e Bilhares, respectivamente.

Pedalar e patins também é possível ser feito apenas no Parque dos Bilhares, que dispõe de faixa exclusiva, além de oferecer o serviço de aluguel de patins e bicicletas.

Tirolesa e rapel já são considerados como esportes na categoria dos radicais, onde já requer um maior investimento financeiro para ser praticado, além de manutenção contínua, pois o risco de acidentes é grande. Em alguns parques nacionais pelo país é possível desfrutar de tal aventura.

Programas familiares como piqueniques também ainda não são encarados com naturalidade para ser desenvolvido nos parques urbanos de Manaus. Certamente por um fator cultural, as pessoas não possuem tal hábito, diferente, por exemplo, de outros estados brasileiros, que aos fins de semana as famílias e/ou amigos dedicam um tempo para tal atividade. Antunes et al., (2013), em uma pesquisa feita em um parque do Rio Grande do Sul, aponta as seguintes atividades que mais destacaram-se de acordo com os entrevistados (Figura 24), dentre elas, o piquenique:

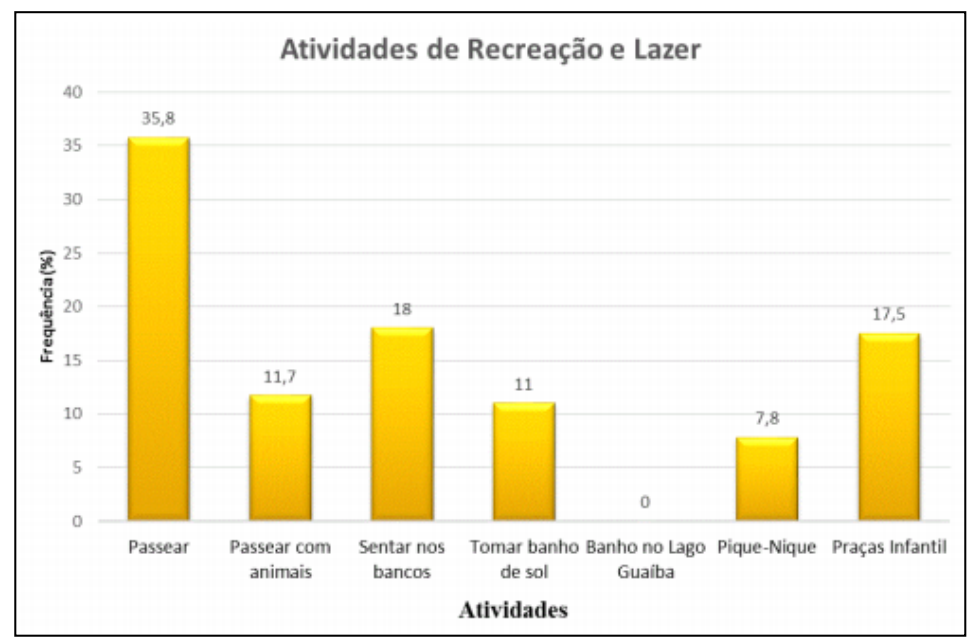

Figura 24. Atividades de recreação e lazer realizadas pelos usuários no Parque. Fonte: Antunes et al., (2013). 
Shows culturais também merecem destaque, uma vez que alguns parques de Manaus já possuem essa atividade em suas programações, como no caso do Parque do Mindu e dos Bilhares, que dispõe de anfiteatro em sua infraestrutura. Talvez o que seja preciso venha ser uma programação sistemática, com determinada frequência de tempo, para que as pessoas possam ter o hábito de prestigiar tais eventos.

Alguns entrevistados deixaram algumas sugestões, visando um melhor bem-estar durante as visitas nos parques:

Que os parques poderiam ter uma equipe médica ou alguém especializado em primeiros socorros; Que os parques que possuem programações destinadas a exercícios físicos e prática de esportes pudessem dispor de professores ou educadores físicos, como no parque Jefferson Peres;

Que os parques pudessem dispor de academia ao ar livre;

Possam ter livrarias/revistarias;

Programas regulares e frequentes de doações de mudas;

Melhorar em aspectos de infraestruturas, como por exemplo, iluminação, aumentando a segurança;

Ampliar a divulgação e marketing das ações desenvolvidas.

\section{CONCLUSÕES}

Os parques urbanos são importantes para a qualidade de vida ambiental e social nas cidades e surgem para minimizar um pouco do desconforto social no meio urbano. A percepção dos atores urbanos determina o quão um uso é viável ou inviável na composição de um mosaico.

Fundamentado na base teórica, juntamente com auxílio das pesquisas de campo, pode-se constatar que:

- Os valores de intelecto e de idade não garantiram os conhecimentos voltados às questões ambientais, haja vista que algumas situações ambientais ainda não são claras para os entrevistados;

- Nem todos os entrevistados ainda possuem interesse em atividades e em práticas ambientais, bem como o nível de importância que atribuem;

- Ainda há uma pequena parte de pessoas que desconhecem os parques na Cidade de Manaus e confundem a caracterização e identidade de um parque;

- Como negativo, conferem à segurança e resíduos nas trilhas como aspectos que precisam ser melhorados;

- Visitam com pouca frequência os parques de Manaus;

- Os entrevistados gostariam de praticar outras atividades de lazer, nem sempre compatíveis com a realidade de cada parque em Manaus.

- As visões e expectativas futuras dos entrevistados para com os parques de Manaus são, baseado nos relatos:

- Que o visitante seja bem informado, que seja comprometido com as causas ambientais e que sejam envolvidos em ações de sensibilização desenvolvidas pelos parques;

- Que haja a produção e distribuição de materiais informativos nos parques (como folders, cartilhas e cartazes atualizados sobre as questões ambientais);

- Que técnicas em educação e interpretação ambiental sejam adotadas;

- Que possa existir em todos os parques guias, guardas e monitores capacitados;

- Que um sistema de segurança possa ser implementado ou melhorado em todos os parques;

- Que possa ser posto em prática um sistema de sinalização atualizado e instalado para que os visitantes possam ter dinamicidade no decorrer de sua visita (trilhas autointerpretativas);

- Que haja um programa de manutenção periódica a ser desenvolvido para conservação dos parques.

Cabe às autoridades competentes pôr em prática as necessidades e expectativas abordadas neste trabalho, visando sempre a promoção do lazer, do entretenimento e do bem-estar de quem usa os parques da cidade. 


\section{REFERÊNCIA}

MELLAZO, G.C. 2005. A percepção ambiental e educação ambiental: uma reflexão sobre as elações interpessoais e ambientais no espaço urbano. Olhares \& Trilhas . Uberlândia, Ano VI, n. 6, p. 45-51,

SILVA, L. J. M. 2003. Parques urbanos: a natureza na cidade - Uma análise da percepção dos atores urbanos. Dissertação de Mestrado em Desenvolvimento Sustentável da Universidade de Brasília. 114p.

BROWNE, K. \& WHITAKER, B. 1973. Parks for People. Schocken Books. New York. 142p.

HILDEBRAND, E.; GRAÇA, L. R.; MILANO, M. S. 2001. Distância de Deslocamento dos Visitantes dos Parques Urbanos em Curitiba-PR. Floresta e Ambiente. V. 8, n.1, pag.76-83.

REIS, R. S. 2001. Determinantes Ambientais para a Realização de Atividades Físicas nos Parques Urbanos de Curitiba: Uma Abordagem Sócio Ecológica da Percepção dos Usuários. Dissertação (Mestrado em Educação Física) - Centro de Desportos da Universidade Federal de Santa Catarina. Florianópolis, SC. 101 p.

PEREIRA, M. 2003. Percepção Sonora no Espaço Público: Indicadores de Tolerância ao Ruído na Cidade do Rio de Janeiro. Anais do ENCAC - ELACAC 2003, Curitiba, PARANÁ, Brasil - 5 a 7 de novembro.

CHIZZOTTI, A. 1998. Pesquisa em ciências humanas e sociais. $3^{\mathrm{a}}$ ed. São Paulo: Cortez.

CANDIANI, G.; VITA, S.; SOUZA, W.; FILHO, W. 2004. Educação ambiental: percepção e práticas sobre o meio ambiente de estudantes do ensino fundamental e médio. Revista Eletrônica do Mestrado em Educação Ambiental, v.12, p.74-89.

WHYTE, A.V.T. 1978. La perception de l'environment: lignes directrices méthodologiques pour les études sur le terrain. UNESCO, Paris, França, 134 p.

MACHADO, L. M. C. P. 1999. A percepção do meio ambiente como suporte para a educação ambiental. In: POMPÊO, M. L.M. (ed.) Perspectivas na Limnologia no Brasil. União, 13 p.

ADGER, W. N. et al. 2001. Advancing a Political Ecology of Global Environmental Discourses. Development and Change, v. 32, n. 4, p. 681-715.

MACNAGHTEN, P. 2003. Embodying the environment in everyday life practices. The sociological review, v. 51, n. 1, p. $62-84$.

MYERS, G.; MACNAGHTEN, P. 1998. Rhetorics of environmental sustainability: commonplaces and places. Environment and Planning A, v. 30, n. 2, p. 333-353.

HOBSON, K. 2003. Thinking Habits into Action: the role of knowledge and process in questioning household consumption practices. Local environment, v. 8, n. 1, p. 95-112.

MACNAGHTEN, P. 2003. Embodying the environment in everyday life practices. The sociological review, v. 51, n. 1, p. $62-84$.

MMA. 2013. Sistema Nacional de Unidades de Conservação. In: http://www.mma.gov.br/areas-protegidas/ unidades-de-conservacao/categorias. Acesso em: 21 de dez. de 2013.

ABREU, A. H. 2004. Áreas Verdes e Municípios. Acesso em 21 de jan. de 2014. Disponível em: < http:// www.mpsc.mp.br/portal/conteudo/cao/cme/areas_verdes_e_municipios_cme.pdf>.

LOBODA, C. R.; ANGELIS, B. L. D. 2005. Áreas Públicas Urbanas: conceito, uso e funções. Ambiência. Guarapuava, PR, v.1 n.1, p. 125-139, jan./jun. ISSN 1808 - 0251. 
GOMES, M. A. S. 2005. As praças de Ribeirão Preto-SP: uma contribuição geográfica ao planejamento e à gestão dos espaços públicos. 204 f. Dissertação (Mestrado) Universidade Federal de Uberlândia, Programa de Pós-Graduação em Geografia. Uberlândia.

NOGUEIRA, A.; WANTUELFER, G. 2002. Florestas Urbanas: planejamento para melhoria da qualidade de vida. Viçosa: Aprenda Fácil.

TROPPMAIR, H.; GALINA, M. H. 2003. Áreas verdes. In: Território \& Cidadania. Rio Claro, SP, ano III, $\mathrm{n}^{\mathrm{o}} 2$, jun-dez.

SANTOS, L. A. R. 2013. Parques Urbanos: uma proposta de atividades de Divulgação Cientifica para o Parque da Cidade do Porto. Dissertação de Mestrado em Ecologia, Ambiente e Território. Universidade do Porto, Portugal. 104p.

LADEIRA. A. S.; RIBEIRO, A. G.; DIAS, H. C. T.; GONÇALVES, C. E.; SCHAEFER, R.; FERNANDES FILHO, E.; OLIVEIRA FILHO, A. T. 2007. O perfil dos visitantes do Parque Estadual do Ibitipoca (PEIb), Lima Duarte, MG. R. Árvore, Viçosa-MG, v.31, n.6, p.1091-1098.

TOMIAZZI, A. B.; VILLARINHO, F. M.; MACEDO, R. L. G.; VENTURIN, N. 2006. Perfil dos visitantes do Parque Natural Municipal do Mendanha, município do Rio de Janeiro-RJ. CERNE, vol. 12, núm. 4, outubro-dezembro, pp. 406

SILVA, L. J. M. 2003. Parques urbanos: a natureza na cidade - Uma análise da percep̧ça dos atores urbanos. Dissertação de Mestrado em Desenvolvimento Sustentável da Universidade de Brasília. 114p.

SANTOS, L. A. R. 2013. Parques Urbanos: uma proposta de atividades de Divulgação Científica para o Parque da Cidade do Porto. Dissertação de Mestrado em Ecologia, Ambiente e Território. Universidade do Porto, Portugal. 104p.

LADEIRA. A. S.; RIBEIRO, A. G.; DIAS, H. C. T.; GONÇALVES, C. E.; SCHAEFER, R.; FERNANDES FILHO, E.; OLIVEIRA FILHO, A. T. 2007. O perfil dos visitantes do Parque Estadual do Ibitipoca (PEIb), Lima Duarte, MG. R. Árvore, Viçosa-MG, v.31, n.6, p.1091-1098.

TAKAHASHI, L. Y.; MARTINS, S. S. 1990. O perfil dos visitantes de um Parque Municipal situado no perímetro urbano. In: Encontro Nacional sobre Arborização Urbana. Curitiba. UFPR/FUPEF, p. 197-210.

COSTA, R. G. S.; BENACHIO, M. V.; BORGES, A. A. S.; COLESANTI, M. T. M. 2011. Uso, afetividade e percep̧̧ão: um estudo da satisfação dos frequentadores do parque do sabiá em Uberlândia-MG. Revista de Geografia (UFPE) V. 28, No. 1, 11pg.

MOREIRA, V. B.; SILVA, G. O.; JUSTINO, A. S.; SANTOS, C. A.; POMPEU, D. S. S.; DENER, F.; SANTOS, G. S.; LEMES, J. F.; SOUZA, J. R.; SILVA, M. C.; RESENDE, P. S. SILVA, T. S.; SOARES, B. R. 2011. Os parques urbanos de Uberlândia - MG: Levantamento e caracterização destes espaços a partir da visão de seus usuários. Observatorium: Revista Eletrônica de Geografia, v.3, n.8, p. 02-26.

SEMMAS. 2013. Acesso em 21 de jan. de 2014. Disponível em: < http://semmas.manaus.am.gov.br/unidades-de-conservacao/>.http://jardimbotanicodemanaus.org>.

PREFEITURA MUNICIPAL DE MANAUS. 2013. Disponível em: < http://www.manaus.am.gov.br/ manaus/mapa-e-dados/2013>.

ANTUNES, G. A.; MENEZES, J. A.; CANDEMIL, V. M.; COUTO, S. L.; OJEDA, T. F. M.; VELHO, L. F. 2013. Caracterização socioambiental dos usuários do Parque Marinha do Brasil, Porto Alegre/RS. In: IV Congresso Brasileiro de Gestão Ambiental. 7 p. 